\title{
MORGAGNI HERNIA IN THE ADULT PATIENT: A CASE REPORT
}

\author{
Vladimir Joksimović1,2, Nikola Jankulovski ${ }^{1,2}$, Svetozar Antović1,2, Stefan Jović2, \\ Marija Joksimović2,3
}

\begin{abstract}
Congenital diaphragmatic hernias ( $\mathrm{CDHs}$ ) occur from a disruption in the muscular formation of the diaphragm, resulting in herniation of abdominal contents into the thoracic cavity (12). First described by Giovanni Batista Morgagni, the anteromedial sternocostal location of diaphragmatic hernia through the defect located between the muscle fibres of the xiphisternum and the costal margin is a rare type of $\mathrm{CDH}$ and accounts for only $2 \%$ to $3 \%$ of cases of all $\mathrm{CDHs}$.

In the neonatal patients, the most common symptoms are pulmonary hypertension and respiratory distress, and in adult patients, these are dyspnea, cough, chest pain and obstruction symptoms.

In this case report, the patient (male, 66 years) reported one month lasting tachycardia, upper abdominal pain and discomfort, claiming certain alleviation of the symptoms in upright position. He had medical history of cardiac disease. The diagnosis was presumed on plain radiogram of the thorax and it was confirmed with CT scan of thorax and abdomen. The patient was treated surgically with primary closure of the diaphragmatic defect.
\end{abstract}

Acta Medica Medianae 2020;59(3):108-111.

Key words: Morgagni hernia, surgical treatment, diaphragmatic hernia

\footnotetext{
${ }^{1}$ University Clinic for Digestive Surgery, Skopje, North Macedonia

${ }^{2}$ Ss. Cyril and Methodius University in Skopje, Faculty of Medicine, Skopje, North Macedonia

${ }^{3}$ University Clinic for Gynaecology and Obstetrics, Skopje, North Macedonia
}

Contact: Vladimir Joksimović

Mother Tereza, 1000 Skopje, North Macedonia

E-mail: vladimirjoksimovic@hotmail.com

\section{Introduction}

Morgagni hernia consists of a defect in the anterior diaphragm, being more common on the right and allowing herniation of abdominal contents to the thorax $(1,2)$. Morgagni hernia is the rarest form of congenital hernia which presents in 2 to $5 \%$ of all cases (2).

\section{Case report}

We report a case of unilateral, right sided Morgagni hernia diagnosed after a previously esta- blished suspicion based on a chest radiograph. The patient was immediately diagnosed and successfully rescued by surgical hernia repair.

A 66-year-old male patient presented with one month history of tachycardia, upper abdominal pain, right subcostal discomfort, fatigue, claiming certain alleviation of the symptoms in upright position. He had a medical history of cardiac disease, however, investigations discarded the cardiac origin of the symptoms. The patient reported no previous trauma. Abdominal palpation revealed soft abdominal wall, with no signs of peritonitis, with mild soreness in the epigastrium. The diagnosis was presumed on plain radiogram of the thorax and it was confirmed with CT scan of the thorax and abdomen.

\section{Treatment}

Elective surgical treatment with laparotomy approach (upper midline laparotomy) was performed. We revealed $4 \mathrm{~cm}$ right diaphragmatic hernia containing almost the entire stomach. Reposition of the stomach into the abdominal cavity and hernia sac excision were undertaken. The diaphragmatic defect was closed using 1/0 Prolene suture. The patient made an uneventful recovery, being discharged on the $3^{\text {th }}$ postoperative day. The patient was scheduled for the first chest radiograph control at the end of the current month. 


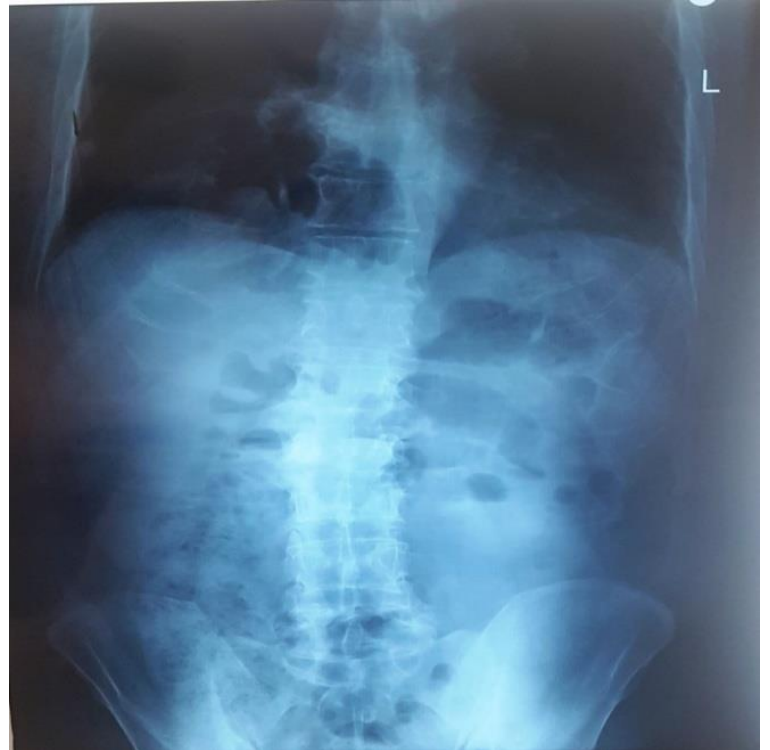

Figure 1. Chest $X-$ Ray in anterior view, right paracardiac opacity (inconclusive, did not exclude diaphragmal hernia, not tumorous formation)
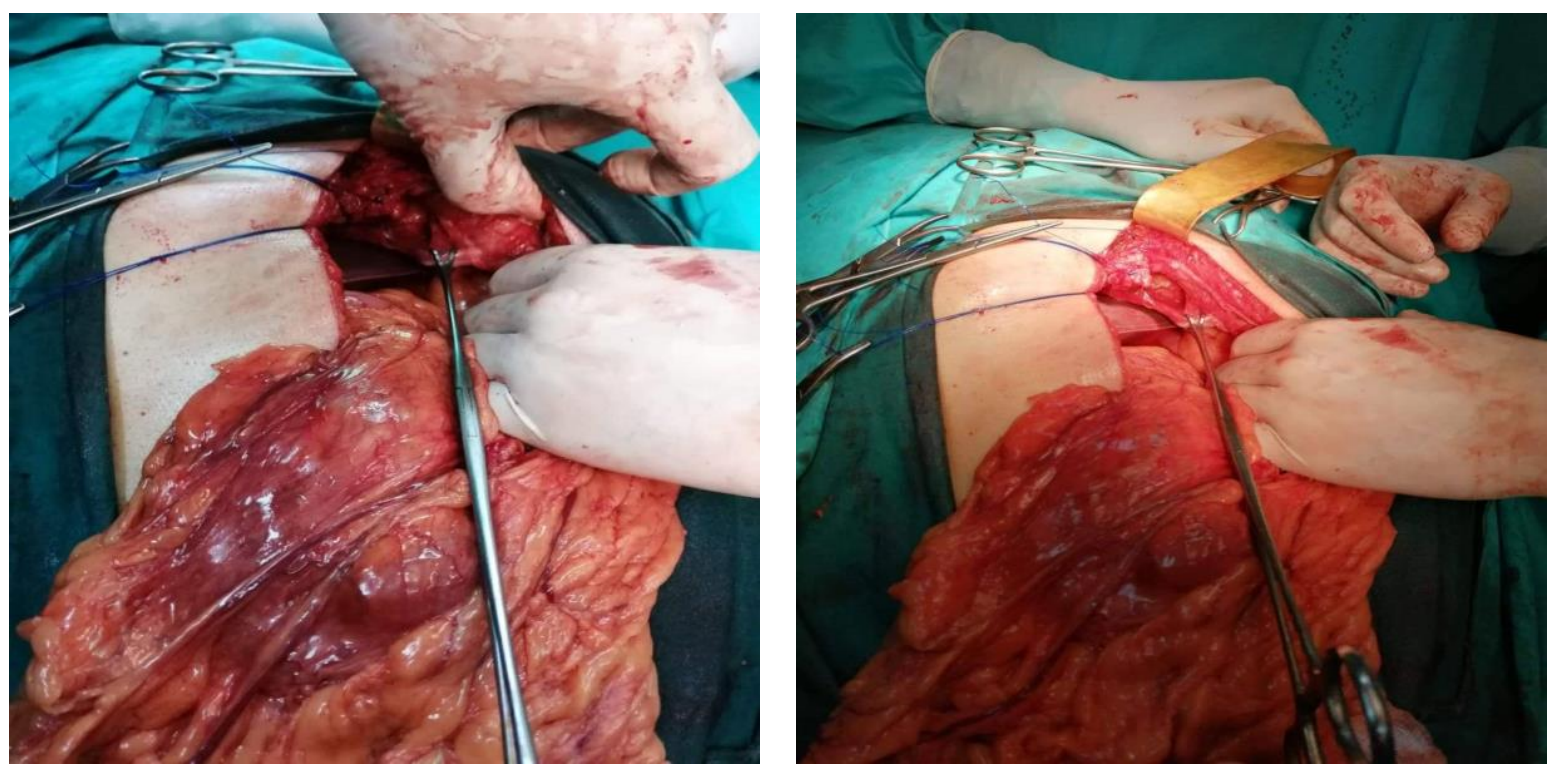

Figure 3. Operative material after reposition of stomach

\section{Discussion}

Morgagni hernias develop due to the lack of fusion of the sternal and crural portions of the diaphragm (3). Most of the cases are diagnosed in newborns or in the early childhood. The presence in adulthood is very rare, most remain asymptomatic. Majority of cases are discovered incidentally (chest $\mathrm{X}$-Ray). When symptomatic, it is usually associated with chronic respiratory symptoms or gastrointestinal involvement with occlusive symptoms (4).

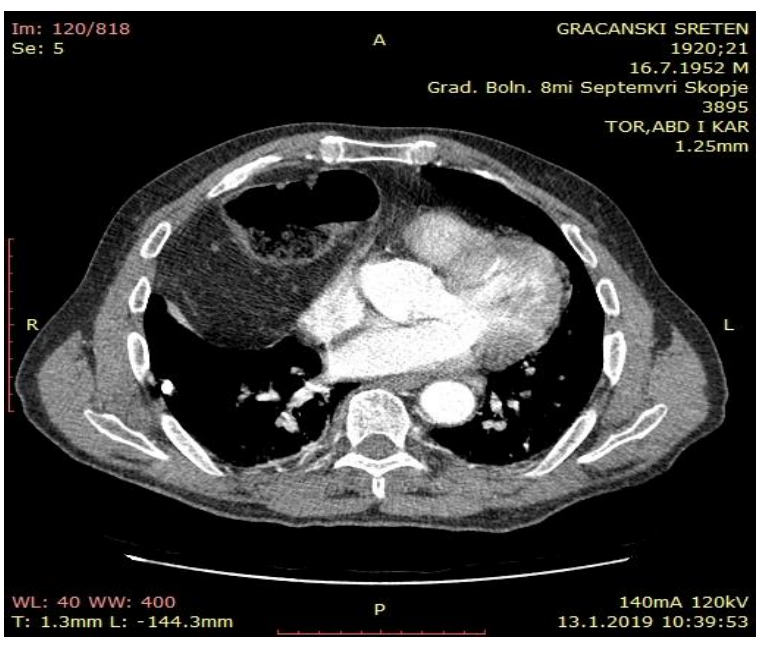

Figure 2. CT scan showing anterior right diaphragmatic Morgagni hernia with stomach content in the right hemithorax 
especially for elective repairs $(10,11,12)$. This is the second case of Morgagni hernia in the last ten years in digestive surgery in Skopje.

\section{Conclusion}

The unusual presentation highlights the difficulties in diagnosis. A high index of suspicion is required in each symptomatic patient, due to the possibility of life-threatening complications. Early diagnosis and surgery are lifesaving.

\section{Acknowledgement}

We are thankful to the patient for allowing us to use his information as well as to the whole team for their assistance during the operation.

\section{References}

1. Arora S, Haji A. Adult Morgagni hernia: the need for clinical awareness, early diagnosis and prompt surgical intervention. Ann R Coll Surg Eng 2008;90:694-5.

[CrossRef] [PubMed]

2. Loong $\mathrm{T}$, Kocher $\mathrm{H}$. Clinical presentation and operative repair of hernia of Morgagni. Postgrad Med J 2005;81: 41-4. [CrossRef] [PubMed]

3. Daneshvar S, Shriki J, Sohn H, Rahimtoola SH. Morgagni-type diaphragmatic hernia presenting as an abnormal cardiac silhouette. Am J Med 2010;123:e11-2.

[CrossRef] [PubMed]

4. Marinceu D, Loubani M, O'Grady H. Late presentation of a large Morgagni hernia in an adult. BMJ Case Rep 2014:15;2014:bcr2013202440. [Crossref] [PubMed]

5. Komatsu T, Takahashi Y. Is this a mediastinal tumor? A case of Morgagni hernia complicated with intestinal incarceration mistaken for the mediastinal lipoma previously. Int J Surg Case Rep 2013;4:302-4.

[CrossRef] [PubMed]

6. Shah RS, Sharma PC, Bhandarkar DS. Laparoscopic repair of Morgagni's hernia: An innovative approach. J Indian Assoc Pediatr Surg 2015;20(2):68-71. [CrossRef] [PubMed]
7. Kashiwagi H, Kumagai K, Nozue M, Terada Y. Morgagni hernia treated by reduced port surgery. Int J Surg Case Rep 2014;5(12):1222-4.

[CrossRef] [PubMed]

8. Aydin $Y$, Altuntas $B$, Ulas $A B$, Daharli $C$, Eroglu $A$. Morgagni hernia: transabdominal or transthoracic approach? Acta Chir Belg 2014;114(2):131-5. [CrossRef] [PubMed]

9. Godazandeh G, Mortazian M. Laparoscopic Repair of Morgagni Hernia Using Polyvinylidene Fluoride (PVDF) Mesh. Middle East J Dig Dis 2012;4(4):232-5. [PubMed]

10. Berardi RS, Tenquist J, Sauter D, Devine D, Halvorson P. et al. An update on the surgical aspects of Morgagni's hernia. Surg Rounds 1997;20:370-6.

11. Aghajanzadeh $M$, Khadem $S$, Khajeh Jahromi $S$, Gorabi HE, Ebrahimi H, Maafi AA. Clinical presentation and operative repair of Morgagni hernia. Interact Cardiovasc Thorac Surg 2012;15(4):608-11. [CrossRef] [PubMed]

12. Restrepo R, Vavricka T, Leahy J. Colonic Dyspnea and the Morgagni Hernia: A Rare Adult Diagnosis. Fed Pract 2015;32(8):21-23. [PubMed] 


\title{
MORGAGNI HERNIJA KOD ODRASLOG BOLESNIKA: PRIKAZ SLUČAJA
}

\author{
Vladimir Joksimović1,2, Nikola Jankulovski ${ }^{1,2}$, Svetozar Antović1,2, Stefan Jović2, \\ Marija Joksimović2,3
}

\begin{abstract}
${ }^{1}$ JZU Univerzitetska klinika za digestivnu hirurgiju, Skoplje, Severna Makedonija
¿Univerzitet "Sv. Ćirilo i Metodije“, Medicinski fakultet, Skoplje, Severna Makedonija

${ }^{3}$ JZU Univerzitetska klinika za ginekologiju i akušerstvo, Skoplje, Severna Makedonija
\end{abstract}

Kontakt: Vladimir Joksimović

Majka Tereza, 1000 Skoplje, Severna Makedonija

E-mail: vladimirjoksimovic@hotmail.com

Kongenitalne diafragmalne hernije (CDHs) dešavaju se zbog prekida mišićne formacije dijafragme, što dovodi do hernijacije, odnosno prelaska abdominalnog sadržaja u torakalnu šupljinu. Prvi opis dat od strane Giovanija Batista Morgagnija glasi da anteromedijalne sternokostale lokalizacije dijafragmalne hernije, kroz defekt lokalizovan između misićnih vlakana pored sternuma i rebarnih ivica, predstavljaju retki tip $\mathrm{CDH}$ i odnose se na samo $2 \%$ do $3 \%$ svih slucajeva $\mathrm{CDH}$.

Kod neonatalnih bolesnika, najčešći simptomi su plućna hipertenzija i respiratorni distres sindrom, a kod odraslih bolesnika to su dispneja, kašalj, bol u grudima i opstruktivni simptomi.

U ovom prikazu slučaja, bolesnik (muškarac, 66 godina) imao je tahikardiju, bol u gornjem delu trbuha i nelagodnosti, u trajanju od mesec dana, ali sa ublažavanjem svih simptoma u uspravnom položaju. On ima medicinsku anamnezu srčanog oštećenja. Dijagnoza je pretpostavljena na osnovu radiograma toraksa, a potvrđena je putem CT toraksa i abdomena. Bolesnik je tretiran hirurški, sa primarnim zatvranjem dijafragmatičnog defekta.

Acta Medica Medianae 2020;59(3):108-111.

Ključne reči: Morgagni hernija, hiruški tretman, dijafragmalna hernija 